\title{
Evaluation of Potential Fungicides and Bio Agents for the Management of Pea Downy Mildew and Yield under Field Condition
}

\author{
Puja Pandey $^{1 *}$, K.P.S. Kushwaha ${ }^{2}$ and Vinod Upadhyay ${ }^{3}$
}

${ }^{1}$ Department of Plant Pathology, Anand Agricutural University, Anand, Gujarat, India

${ }^{2}$ Department of Plant Pathology, G.B. Pant University of Agriculture and Technology, Uttarakhand, India

${ }^{3}$ Regional Agricultural Research Station, Assam Agricultural University, Jorhat, India *Corresponding author

\begin{tabular}{|c|c|}
\hline & A B S T R A C T \\
\hline & \multirow{7}{*}{$\begin{array}{l}\text { Field trial was conducted to evaluate the efficacy of different chemical } \\
\text { fungicides and bio control agents against downey mildew disease of pea } \\
\text { during 2012-2013 and 2013-2014 and it was observed that all the } \\
\text { fungicides were effective for the management of disease as compare to } \\
\text { control. Among } 12 \text { chemical fungicides maximum reduction in disease } \\
\text { severity was observed in case of treatment Penflufen + Trifloxystrobin } \\
\text { (64.79) followed by Metalaxyl (52.51), Fosetyl Al (51.80) were found to be } \\
\text { best. It was found that maximum percent increase in yield was recorded in } \\
\text { treatment Metalaxyl 4\% + Mancozeb 64\% (54.39) followed by Metalaxyl } \\
\text { (45.72), Nativo (45.06), Trifloxystrobin (44.67) and Penflufen + } \\
\text { Trifloxystrobin (44.67). }\end{array}$} \\
\hline Keywords & \\
\hline Fungicides, & \\
\hline $\begin{array}{l}\text { Yield, Downy } \\
\text { mildew severity. }\end{array}$ & \\
\hline Article Info & \\
\hline $\begin{array}{l}\text { Accepted: } \\
12 \text { October } 2017\end{array}$ & \\
\hline $\begin{array}{l}\text { Available Online: } \\
10 \text { December } 2017\end{array}$ & \\
\hline
\end{tabular}

\section{Introduction}

In all over the world, India is the largest producer, consumer and importer of pulses. In India area under pulses is around 25.1 million hectares and annual production of pulses is 22.14 million tonnes (Anonymous, 2017). Pulses are one of the most important sources of energy that have been extensively used as source of basic protein and energy. Along with proteins, pulses are also rich in minerals like iron, magnesium, zinc and potassium and vitamins (Anonymous, 2017b).Among all pulses larger imports of dry peas in recent years due its lower international prices have resulted in its increased share in the domestic pulse consumption. Because of the biotic and abiotic stresses there is high level of fluctuations in pulse production and prices farmers are not very interested on taking up pulse as cultivation. Low pulse yield in India compared to other countries is because of poor spread of improved varieties and technologies, climatic changes, vulnerability to pests and diseases and generally declining growth rate of total factor productivity. For consumption seeds are separated and used as vegetable or pulse. Peas are highly nutritive 
and contain digestible protein $(7.2 \mathrm{~g} / 100 \mathrm{~g})$, Carbohydrate $(15.8 \mathrm{~g})$, Vitamin-C $(9 \mathrm{mg})$, phosphorus (139 mg) and minerals. Pea seeds generally contain 23 per cent protein, 48 per cent starch, 8 per cent sugar, 4 per cent lipid, 7 per cent crude fiber and 3 per cent ash (Duke and Ayensu, 1985). Like any legume crop, pea is also an integral component of sustainable agriculture because of its soil enriching and conditioning properties. Cultivated garden pea is not seen in wild state and it might have been originated from wild field pea or other related species. During 2014-15, field pea was grown in an area of $0.76 \mathrm{mha}$ and production of $0.84 \mathrm{mt}$ and yield of $1100 \mathrm{~kg} / \mathrm{ha}$ in India. In Uttarakhand, area, production and productivity of pea during 2012-13 was 61.0 thousand ha, 51.3 thousand tones and $841 \mathrm{~kg} / \mathrm{ha}$, respectively (Anonymous, 2014).The annual export of pea in 2016-17 was 6.43 thousand tonnes which constituted 6.53 per cent of the total pulse export from India (Anonymous, 2017a).

Pea is affected by a number of diseases caused by fungi (rust, powdery mildew, downy mildew, root rot, alternaria blight, aschochyta blight, wilt, anthracnose, cercospora leaf spot, damping off, seedling rot etc.), bacteria (bacterial blight and brown spot), nematodes (cyst nematode, lesion nematode and root-knot nematode) and viruses (cucumber mosaic virus, pea early browning virus, pea enation mosaic, pea mosaic, pea seed borne mosaic, pea streak and pea stunt). These diseases if occurred in favourable condition may cause significantly decrease both in yield and quality.

The disease Downy mildew is caused by Peronosporapisi Syd, and is most common foliar disease of the pea (Pisum sativum L.). In susceptible varieties, it may cause yield loss up to 55 per cent (Clark and SpencerPhillips 2000). It occurs commonly in the vegetative stage of the crop leading to significant losses all around the globe wherever the peas are grown (Amey and Spencer- Phillips, 2006). Variable ripening is one of the adverse effects of downy which may create serious problems for the processing industries (Dixon, 1981). Epidemics of the disease were reported in the USSR. Hagedorn (1973) reported 60 - 85 per cent pod destruction in epidemic years. The disease results in a substantial diversion of photosynthate from the host to the pathogen, and production of symptoms such as stunted growth, distortion and early death of the infected plant (Mence and Pegg, 1971). This disease mostly affects the plant soon after seedling emergence, but crops may get infected at any stage of growth, particularly during periods of moist, cool weather. The symptom appears usually on the abaxial surface of the leaflets, which get covered with a fluffy grey spore mass. Infected plants may turn yellow while producing abundant conidia, which serves as secondary source of infection.

Fungicides play important role in controlling the disease but recently fungicide resistance have been reported. Fungicide resistance management strategies should be applied for effective and sustainable downy mildew control in pea crops. Alternating phenylamides with chemicals with different modes of action, or using phenylamides in mixtures with non-phenylamide chemicals can be used for managing the fungicide resistance. Appropriate alternative or mixture chemicals include cymoxanil, fosetylAl, mancozeb and phosphorous acid. The same strategies should be used for seed treatment to control downy mildew in young crops and for foliar applications of fungicides to control the disease in mature crops. Chang et al., (2013) reported that the plant mortality was much lower with pyraclostrobin and azoxystrobin than for chlorothanonil, cymoxanil, metalaxyl or QGU 42. In contrast, seed yield was not 
affected by any of the fungicide treatments in 2009 or 2011, but despite of significant differences in plant mortality, all of the treatments except cymoxanil increased yield compared to the control. According to Falloon et al., (2000) seed treatments with metalaxyl or oxadixyl (systemic phenylamide fungicides) were ineffective for downy mildew control in young pea seedlings inoculated with field collections of $P$. viciae, and that seed treatments containing cymoxanil or fosetyl-Al protected seedlings from infection by metalaxyl-resistant collections.

Among the fungicides, pyraclostrobin, azoxystrobin and metalaxyl was found to be most promising for reducing downy mildew. Azoxystrobin and pyraclostrobin are strobilurin fungicides that are locally systemic and have both protective and curative effects. Azoxystrobin has also been observed in inhibiting many stages of the asexual life cycle of Plasmopara viticola (Berk. \& M. A. Curtis) Berl. \& De Toni, the causal agent of grapevine downy mildew (Godwin et al., 1992, 1997) and a close relative of $P$. viciae.

\section{Materials and Methods}

Present investigation was carried out during Rabi 2013-14 and 2014-2015 crop seasons in plot size of $3.0 \times 2.0 \mathrm{~m}^{2}$ in Randomized Block Design (RBD) at N.E. Borlogue Crop Research Centre (NEBCRC) of G.B. Pant University of Agriculture and Technology, Pantnagar.

A field trial was conducted during Rabi 201314 and 2014-2015 crop seasons in plot size of $2.0 \times 0.6 \mathrm{~m}^{2}$ in Randomized Block Design (RBD). The sowing of highly susceptible cultivar 'Arkel' was done with wider spacing of $30 \times 10 \mathrm{~cm}$ in three replications.

Total of twelve different fungicides alone or in combination along with biocontrol agent (Table 2) were evaluated under field conditions. Crop was sprayed twice with each fungicide, at recommended doses. First spray was done at the appearance of symptoms (30 days after sowing) and repeated after 15 days interval, respectively.

Control plot were sprayed with same volume of water. Disease severity was recorded using 0-4 rating scale before the beginning of first spray and subsequent observations were recorded before each spray and finally disease severity was recorded 15 days after last spray. The periodical data were also recorded on downy mildew severity with the initiation of the disease at seven days interval. It was used to determine area under disease progress curve (AUDPC) and ' $r$ ' value for each treatment.

\section{AUDPC (A) value}

Downy mildew severity was quantified using the formula given by Wilcoxson et al., (31).

$$
\underset{i=1}{k} \sum_{i=1}^{k}\left(S_{i}+S_{i-1}\right) d
$$

Where $S_{i}=$ Disease incidence at the end of the week i, $\mathrm{k}=$ Number of successive evaluations of disease, and $\mathrm{d}=$ Interval between two evaluations.

\section{Apparent rate of infection (' $r$ ')}

The apparent rate of infection was calculated using Vanderplank (30) formula:

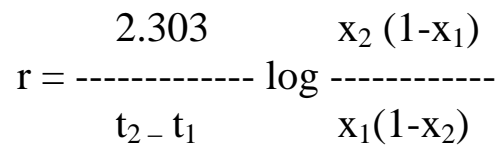

Where, $\mathrm{r}$ is the apparent infection rate in nonlogarithmic phase, $\mathrm{x}_{1}$ is the disease index at initial week time $\left(t_{1}\right), x_{2}$ is the disease index at subsequent week time $\left(\mathrm{t}_{2}\right)$ 


\section{Karl Pearson's correlation coefficient (r)}

$$
r=\frac{1}{n-1} \sum \frac{\left(x_{i}-\bar{X}\right)\left(y_{i}-\bar{Y}\right)}{s_{x} s_{y}}
$$

Where, $\mathrm{r}=$ coefficient of correlation, $\mathrm{X}=\mathrm{x}_{\mathrm{i}}$ $\bar{X}, \mathrm{Y}=\mathrm{yi}-\bar{Y}, S_{x}=$ standard deviation of $\mathrm{x}$ series, $S_{y}=$ standard deviation of y series, $\mathrm{n}=$ number of series

\section{Per cent increase in yield}

Per cent increase in yield $=\frac{\text { Yield in treated plot }(-) \text { Yield in check plot }}{\text { Yield in check plot }} \times 100$

\section{Per cent disease in control}

The data on disease incidence was recorded on a day before spraying and 10 days after each spray and final incidence was recorded before harvest.

The per cent disease inhibition over control was calculated by using the formula given by Vincent (1927).

Percent disesae control $=\frac{(\mathrm{C}-\mathrm{P})}{\mathrm{C}} \times 100$

Where,

$\mathrm{C}=$ Per cent disease in control

$\mathrm{T}=$ Per cent disease in treatment

The data was analyzed statistically by Randomized Block Design (RBD) using SPSS (16.0 version), STPR (GBPUA\&T statistical software) and MS Excel.

\section{Results and Discussion}

A field experiment was conducted during 2013-2014 and 2014-2015 to see the effect of foliar sprays of total twelve fungicides alone and in combination viz. Trifloxystrobin +
Tebuconazole (T1), Metalaxyl (T2), Fosetyl Al(T3), Zineb (T4), Blitox (T5), Mancozeb (T6), Triflloxystrobin (T7), Metalaxyl 4\% + Mancozeb 64\% (T8), Fosetyl Al+ Mancozeb (T9), Pant Bioagent 1(T10), Pant Bioagent 2(T11), Penflufen + Trifloxystrobin (T12) and Control (T13) on disease severity, AUDPC value, apparent rate of infection, test weight, total yield and percent increase in yield over control.

\section{Disease severity (\%)}

Foliar spray with fungicides alone and/or in combination significantly reduced the downy mildew severity in comparison to control, $\mathrm{T}_{13}$ (27.17) (Table 1). The pooled data (2013 \& 2014) on efficacy of chemical fungicides revealed that the per cent downy mildew severity was significantly lowest in $\mathrm{T}_{12}(9.54)$ followed by $\mathrm{T}_{2}$ (12.87), $\mathrm{T}_{1}$ (14.50) $\mathrm{T}_{3}$ (14.96), $\mathrm{T}_{9}$ (15.08), $\mathrm{T}_{11}$ (15.12), $\mathrm{T}_{8}(15.66), \mathrm{T}_{6}$ (15.67), $\mathrm{T}_{7}$ (16.19), $\mathrm{T}_{4}(16.29), \mathrm{T}_{5}(16.96)$ and $\mathrm{T}_{10}$ (17.00).

Treatments $T_{1}, T_{3}, T_{4}, T_{5}, T_{7}, T_{10}$ and $T_{11}$ and treatments $T_{6}, T_{8}$ and $T_{9}$ were at par with each other.

\section{AUDPC ('A' value) and apparent rate of infection (' $r$ ' value)}

' $A$ ' value was found minimum in $T_{12}$ (154.58) with infection rate of 0.030 followed by $\mathrm{T}_{2}$ (212.92) with 0.052 rate of infection, $\mathrm{T}_{1}$ (245.33) with ' $r$ ' value of $0.042, \mathrm{~T}_{3} \mathrm{~T}_{9}$ and $\mathrm{T}_{11}$ (256.67) with infection rate of $0.040, \mathrm{~T}_{7}$ (250.33) with 0.033 rate of infection, $\mathrm{T}_{6}$ and $\mathrm{T}_{8}$ (268.33) with infection rate of $0.039, \mathrm{~T}_{9}$ and $\mathrm{T}_{11}$ (256.67) with ' $\mathrm{r}$ ' value of $0.040, \mathrm{~T}_{4}$ (280.00) with infection rate $0.038, \mathrm{~T}_{5}$ and $\mathrm{T}_{10}$ (291.67) with infection 0.031 and 0.040 .

The maximum AUDPC (475.83) was recorded in control with infection rate of 0.057 (Table 1). 
Table.1 Effect of chemical fungicide and biocontrol agents on downy mildew severity during 2013-14 and 2014-15 (Pooled)

\begin{tabular}{|c|c|c|c|c|c|c|c|c|c|c|c|c|c|}
\hline $\begin{array}{l}\text { Tr. } \\
\text { No. }\end{array}$ & Treatment & $\begin{array}{c}\text { Percent } \\
\text { Disease } \\
\text { Severity } \\
(\mathbf{2 0 1 3}) \\
\end{array}$ & $\begin{array}{c}\text { Percent } \\
\text { Disease } \\
\text { Severity } \\
(\mathbf{2 0 1 4}) \\
\end{array}$ & $\begin{array}{c}\text { Pooled } \\
\text { disease } \\
\text { severity }\end{array}$ & $\begin{array}{c}\text { Per cent } \\
\text { reduction } \\
\text { over control } \\
(\mathbf{2 0 1 3}) \\
\end{array}$ & $\begin{array}{c}\text { Per cent } \\
\text { reduction } \\
\text { over control } \\
(2014) \\
\end{array}$ & $\begin{array}{c}\text { Pooled } \\
\text { reduction } \\
\text { over } \\
\text { control } \\
\end{array}$ & $\begin{array}{c}\text { 'A' } \\
\text { Value } \\
\text { (2013) }\end{array}$ & $\begin{array}{c}\text { 'A' } \\
\text { Value } \\
\text { (2014) }\end{array}$ & $\begin{array}{l}\text { AUDPC } \\
\text { (pooled) }\end{array}$ & $\begin{array}{c}\text { 'r' } \\
\text { Value } \\
\text { (2013) }\end{array}$ & $\begin{array}{c}\text { 'r' } \\
\text { Value } \\
\text { (2014) }\end{array}$ & $\begin{array}{c}\text { 'r' } \\
\text { Value } \\
\text { (pooled) }\end{array}$ \\
\hline $\mathrm{T}_{1}$ & $\begin{array}{l}\text { Trifloxystrobin + } \\
\text { Tebuconazole } \\
\text { (Nativo } 75 \mathrm{WG} \text { ) }\end{array}$ & $15.08^{\mathrm{cd}}$ & $13.91^{\mathrm{bc}}$ & $14.50^{\mathrm{bc}}$ & 47.693 & 45.451 & 46.572 & 256.67 & 233.33 & 245.00 & 0.031 & 0.031 & 0.042 \\
\hline $\mathrm{T}_{2}$ & Metalaxyl 35 WP & $13.16^{\mathrm{d}}$ & $12.58^{\mathrm{c}}$ & $12.87^{\mathrm{c}}$ & 54.353 & 50.667 & 52.510 & 215.83 & 210.00 & 212.92 & 0.055 & 0.049 & 0.052 \\
\hline $\mathrm{T}_{3}$ & $\begin{array}{l}\text { Fosetyl Al } \\
\text { (Aliette } 80 \mathrm{WP} \text { ) }\end{array}$ & $13.66^{\mathrm{bc}}$ & $12.50^{\mathrm{c}}$ & $14.96^{\mathrm{bc}}$ & 52.619 & 50.980 & 51.800 & 245.33 & 210.00 & 256.67 & 0.031 & 0.049 & 0.041 \\
\hline $\mathrm{T}_{4}$ & $\begin{array}{l}\text { Zineb (Dithane Z } \\
78 \text { ) }\end{array}$ & $18.75^{\mathrm{b}}$ & $13.83^{\mathrm{bc}}$ & $16.29^{\mathrm{bc}}$ & 34.964 & 45.765 & 40.364 & 326.67 & 233.33 & 280.00 & 0.034 & 0.044 & 0.038 \\
\hline $\mathrm{T}_{5}$ & Blitox $50 \mathrm{WP}$ & $18.83^{b}$ & $15.08^{\mathrm{b}}$ & $16.96^{\mathrm{bc}}$ & 34.686 & 40.863 & 37.774 & 326.67 & 256.67 & 291.67 & 0.040 & 0.044 & 0.031 \\
\hline $\mathrm{T}_{6}$ & $\begin{array}{l}\text { Mancozeb } \\
\text { (Dithane M-45) }\end{array}$ & $17.58^{\mathrm{bc}}$ & $13.75^{\mathrm{bc}}$ & $15.67^{\mathrm{b}}$ & 39.022 & 46.078 & 42.550 & 303.33 & 233.33 & 268.33 & 0.034 & 0.044 & 0.039 \\
\hline $\mathrm{T}_{7}$ & $\begin{array}{l}\text { Triflloxystrbin } \\
\text { (Flint } 500 \mathrm{WG} \text { ) }\end{array}$ & $15.16^{\mathrm{bc}}$ & $14.75^{\mathrm{bc}}$ & $16.21^{\mathrm{bc}}$ & 47.416 & 42.157 & 44.786 & 260.33 & 240.33 & 250.33 & 0.032 & 0.035 & 0.033 \\
\hline $\mathrm{T}_{8}$ & $\begin{array}{l}\text { Metalaxyl 4\% + } \\
\text { Mancozeb 64\% } \\
\text { (Ridomil MZ 68) }\end{array}$ & $17.41^{\mathrm{bc}}$ & $13.91^{\mathrm{bc}}$ & $15.66^{\mathrm{b}}$ & 39.612 & 45.451 & 42.531 & 303.33 & 233.33 & 268.33 & 0.034 & 0.044 & 0.039 \\
\hline $\mathrm{T}_{9}$ & $\begin{array}{l}\text { Aliette } 80 \mathrm{WP}+ \\
\text { Dithane M-45 }\end{array}$ & $16.33^{\mathrm{bc}}$ & $13.83^{\mathrm{bc}}$ & $15.08^{\mathrm{b}}$ & 43.358 & 45.765 & 44.561 & 280.00 & 233.33 & 256.67 & 0.036 & 0.044 & 0.040 \\
\hline $\mathrm{T}_{10}$ & $\begin{array}{l}\text { Pant Bioagent } 1 \\
\text { (Trichoderma } \\
\text { harzianum) }\end{array}$ & $18.83^{\mathrm{b}}$ & $15.16^{\mathrm{b}}$ & $17.00^{\mathrm{bc}}$ & 34.686 & 40.549 & 37.618 & 326.67 & 256.67 & 291.67 & 0.040 & 0.040 & 0.040 \\
\hline $\mathrm{T}_{11}$ & $\begin{array}{l}\text { Pant Bioagent } 2 \\
\text { (Pseudomonas } \\
\text { fluorescens) }\end{array}$ & $16.33^{\mathrm{bc}}$ & $13.91^{\mathrm{bc}}$ & $15.12^{\mathrm{bc}}$ & 43.358 & 45.451 & 44.404 & 280.00 & 233.33 & 256.67 & 0.036 & 0.044 & 0.040 \\
\hline $\mathrm{T}_{12}$ & $\begin{array}{l}\text { Penflufen } \\
\text { +Trifloxystrobin } \\
\text { (Trilex } \\
\text { Component A) }\end{array}$ & $9.75^{\mathrm{e}}$ & $9.33^{\mathrm{d}}$ & $9.54^{\mathrm{d}}$ & 66.181 & 63.412 & 64.796 & 157.50 & 151.67 & 154.58 & 0.030 & 0.030 & 0.030 \\
\hline $\mathrm{T}_{13}$ & Control & $28.83^{\mathrm{a}}$ & $25.50^{\mathrm{a}}$ & $27.17^{\mathrm{a}}$ & 0.000 & 0.000 & 0.000 & 495.83 & 455.00 & 475.42 & 0.062 & 0.053 & 0.057 \\
\hline
\end{tabular}

Means sharing different alphabetical $(a, b, c)$ superscripts in a column significantly different $(\mathrm{P}<0.05)$, according to Duncan's multiple range test. 
Table.2 List of fungicides alone and in combination used in experiment

\begin{tabular}{|c|l|c|}
\hline S. No. & \multicolumn{1}{|c|}{ Treatments } & Doses \\
\hline 1 & Trifloxystrobin + Tebuconazole (Nativo 75 WG) & $1 \mathrm{~g} / \mathrm{l}$ \\
\hline 2 & Metalaxyl 35 WP & $1 \mathrm{~g} / \mathrm{l}$ \\
\hline 3 & Fosetyl Al (Aliette 80 WP) & $1.5 \mathrm{~g} / 1$ \\
\hline 4 & Zineb (DithaneZ 78) & $2 \mathrm{~g} / \mathrm{l}$ \\
\hline 5 & Blitox 50 WP & $3 \mathrm{~g} / \mathrm{l}$ \\
\hline 6 & Mancozeb (Dithane M-45) & $3 \mathrm{~g} / \mathrm{l}$ \\
\hline 7 & Triflloxystrbin (Flint 500 WG) & $1 \mathrm{~g} / \mathrm{l}$ \\
\hline 8 & Metalaxyl 4\% + Mancozeb 64\% (Ridomil MZ 68) & $15 \mathrm{~g} / 1$ \\
\hline 9 & Aliette 80 WP + Dithane M-45 & $0.75 \mathrm{~g}+1.5 \mathrm{~g} / \mathrm{l}$ \\
\hline 10 & Pant Bioagent 1 (Trichoderma harzianum) & $10 \mathrm{~g} / 1$ \\
\hline 11 & Pant Bioagent 2(Pseudomonas fluorescens) & $10 \mathrm{~g} / 1$ \\
\hline 12 & Penflufen +Trifloxystrobin (Trilex Component A) & $1 \mathrm{ml} / 1$ \\
\hline 13 & Control & - \\
\hline
\end{tabular}

Table.3 Effect of different treatments on yield during 2013 and 2014

\begin{tabular}{|c|c|c|c|c|c|}
\hline \multirow{2}{*}{ Tr.No. } & \multirow{2}{*}{ Treatment Details } & \multicolumn{2}{|c|}{ Yield (Kg/ha) } & \multirow{2}{*}{ Mean } & \multirow{2}{*}{$\begin{array}{l}\text { Per cent increase in } \\
\text { yield over check }\end{array}$} \\
\hline & & 2013 & 2014 & & \\
\hline $\mathrm{T}_{1}$ & $\begin{array}{l}\text { Trifloxystrobin + Tebuconazole } \\
\text { (Nativo } 75 \text { WG) }\end{array}$ & $1333.5^{\mathrm{ab}}$ & $1411.0^{\mathrm{ab}}$ & 1372.25 & 45.06 \\
\hline $\mathrm{T}_{2}$ & Metalaxyl 35 WP & $1388.9^{\mathrm{ab}}$ & $1388.87^{\mathrm{b}}$ & 1388.885 & 45.72 \\
\hline $\mathrm{T}_{3}$ & Fosetyl Al (Aliette $80 \mathrm{WP}$ ) & $1037.5^{\mathrm{bc}}$ & $1009.83^{f}$ & 1023.665 & 26.35 \\
\hline $\mathrm{T}_{4}$. & Zineb (Dithane Z 78) & $1286.5^{\mathrm{ab}}$ & $1258.83^{\mathrm{d}}$ & 1272.665 & 40.76 \\
\hline $\mathrm{T}_{5}$ & Blitox $50 \mathrm{WP}$ & $1070.70^{\mathrm{e}}$ & $1383.33^{\mathrm{bc}}$ & 1227.015 & 38.56 \\
\hline $\mathrm{T}_{6}$ & Mancozeb (Dithane M-45) & $1314.2^{\mathrm{ab}}$ & $1328.00^{c}$ & 1321.1 & 42.93 \\
\hline $\mathrm{T}_{7}$ & Triflloxystrobin (Flint $500 \mathrm{WG}$ ) & $1369.5^{\mathrm{ab}}$ & $1355.67^{\mathrm{bc}}$ & 1362.585 & 44.67 \\
\hline $\mathrm{T}_{8}$ & $\begin{array}{l}\text { Metalaxyl 4\% + Mancozeb 64\% } \\
\text { (Ridomil MZ 68) }\end{array}$ & $1660.0^{\mathrm{a}}$ & $1646.17^{\mathrm{a}}$ & 1653.085 & 54.39 \\
\hline $\mathrm{T}_{9}$ & Aliette $80 \mathrm{WP}+$ Dithane M-45 & $940.7^{\mathrm{bc}}$ & $954.50^{\mathrm{f}}$ & 947.6 & 20.44 \\
\hline $\mathrm{T}_{10}$ & $\begin{array}{l}\text { Pant Bioagent } 1 \text { (Trichoderma } \\
\text { harzianum) }\end{array}$ & $982.2^{\mathrm{bc}}$ & $968.33^{\mathrm{f}}$ & 975.265 & 22.70 \\
\hline $\mathrm{T}_{11}$ & $\begin{array}{l}\text { Pant Bioagent } 2 \text { (Pseudomonas } \\
\text { fluorescens) }\end{array}$ & $1245.0^{\mathrm{ab}}$ & $1217.33^{\mathrm{d}}$ & 1231.165 & 38.77 \\
\hline $\mathrm{T}_{12}$ & $\begin{array}{l}\text { Penflufen +Trifloxystrobin } \\
\text { (Trilex Component A) }\end{array}$ & $1369.5^{\mathrm{ab}}$ & $1355.67^{b c}$ & 1362.585 & 44.67 \\
\hline $\mathrm{T}_{13}$ & Control & $760.8^{\mathrm{c}}$ & $747.00^{\mathrm{g}}$ & 753.9 & 0.00 \\
\hline
\end{tabular}

Means sharing different alphabetical $(a, b, c)$ superscripts in a column significantly different $(\mathrm{P}<0.05)$, according to Duncan's multiple range test.

Per cent reduction in disease severity over control

Significant reduction in per cent disease severity was observed in all the treatments over control was observed (Table 1). Maximum reduction in disease severity was observed in case of treatment $\mathrm{T}_{12}$ (64.79) followed by $\mathrm{T}_{2}$ (52.51), $\mathrm{T}_{3}(51.80), \mathrm{T}_{1}$ (46.57), $\mathrm{T}_{7}$ (44.78), $\mathrm{T}_{9}$ (44.56), $\mathrm{T}_{11}$ (44.40), $\mathrm{T}_{6}(42.55)$, $\mathrm{T}_{8}$ (42.53), $\mathrm{T}_{4}$ (40.36), $\mathrm{T}_{5}$ (37.77) and $\mathrm{T}_{10}$ (37.61). Treatments $\mathrm{T}_{9}$ and $\mathrm{T}_{11}$ and treatments $\mathrm{T}_{5}$ and $\mathrm{T}_{10}$ were at par with each other. 


\section{Per cent increase in yield}

Comparison of total yield from all the treatments with control was done through estimation of percent increase in yield over control (Table 3). It was found that maximum percent increase in yield was recorded in treatment $\mathrm{T}_{8}$ (54.39) followed by $\mathrm{T}_{2}(45.72)$, $\mathrm{T}_{1}$ (45.06), $\mathrm{T}_{7}$ and $\mathrm{T}_{12}$ (44.67), $\mathrm{T}_{6}(42.93), \mathrm{T}_{4}$ (40.76), $\mathrm{T}_{11}$ (38.77), $\mathrm{T}_{5}$ (38.56), $\mathrm{T}_{3}$ (26.35), $\mathrm{T}_{10}(22.70)$ and $\mathrm{T}_{9}(20.44)$.

The results of present investigations on efficacy of chemical fungicides against downy mildew disease of pea during both the seasons revealed that all the fungicides were found to be effective in controlling the downy mildew of pea. However, most effective treatment among the chemical fungicide was Penflufen + Trifloxystrobin $\left(\mathrm{T}_{12}\right)$ followed by Metalaxyl $\left(\mathrm{T}_{2}\right)$ and Fosetyl Al $\left(\mathrm{T}_{3}\right)$ and among the bioagents Pant bioagent 2 was the best for management of disease as compare to control. The work was found to be in accordance to work done by several scientists. Chang et al., (2013) reported that plant mortality was lower with pyraclostrobin and azoxystrobin than for chlorothanonil, cymoxanil, metalaxyl or QGU 42. In contrast, seed yield was not affected by any of the fungicide treatments in 2009 or 2011, but despite significance differences in plant mortality, all of the treatments except cymoxanil increased yield compared to the control in 2010. According to Falloon et al., (2000) seed treatments with metalaxyl or oxadixyl (systemic phenylamide fungicides) were ineffective for downy mildew control in young pea seedlings inoculated with field collections of $P$. viciae, and that seed treatments containing cymoxanil or fosetyl-Al protected seedlings from infection by metalaxyl-resistant collections. Among the fungicides, pyraclostrobin, azoxystrobin and metalaxyl showed the most promise for reducing downy mildew. Azoxystrobin and pyraclostrobin are strobilurin fungicides that are locally systemic and have both protective and curative (inhibit spore germination and early infection) effects. Azoxystrobin has a broad spectrum of activity and inhibits many stages of the asexual life cycle of Plasmopara viticola (Berk. \& M. A. Curtis) Berl. \& De Toni, the causal agent of grapevine downy mildew (Godwin et al., 1992, 1997) and a close relative of $P$. viciae.

\section{References}

Amey, R. C. and Spencer-Phillips, P. T. N. 2006. Towards developing diagnostics for downy mildew diseases. Outlooks on Pest Management, 17, 4-8.

Anonymous, 2014.National Council of Applied Economic Research (NCAER). India's Pulses scenario $1 \mathrm{p}$.

Anonymous. (2017b). http://www.agricoop. nic.in.

Anonymous. (2017). http://www.agricoop.nic. in.

Anonymous. (2017a). http://www.agricoop. nic.in.

Chang, K.F., Hwang, S.F., Ahmed, H.U., Strelkov, S.E., Conner, R.L., Gossen, B.D., Bing, D.J. and Turnbull, G.D. 2013. Yield loss and management of downy mildew on field pea in Alberta, Canada. Crop Protection, 46:23-28.

Clark, J. S. C. and Spencer-Phillips, P. T. N. 2000. Downy Mildews. In The Encyclopaedia of microbiology, Volume 2, J. Lederberg, M. Alexander, B. R. Bloom, D. Hopwood, R. Hull, B. H. Inglearski, A. I. Laskia, S. G. Oliver, M. Schaechter, \& W. C. Summers, eds Academic Press, San Diego, USA, 2: $117-129$.

Dixon, G.R. 1981. Downy mildews on peas and beans. In: The downy mildews, D.M. Spencer, ed,87-154, Academic Press, New York, USA, 636p.

Duke, J.A. and Ayensu, E.S. 1985. Medicinal Plants of China. Reference Publications. 
Inc: ISBN 0-917256-20-4. Reference Publications, Algonac, MI (USA).

Falloon, R. E., Follas, G. B., Butler, R. C. and Goulden, D. S. 2000. Resistance in Peronospora viciae to phenylamide fungicides: reduced efficacy of seed treatments of pea (Pisum sativum) and assessment of alternatives. Crop Protection, 19(5): 313-325.

Godwin, J.R., Anthony, V.M., Clough, J.M. and Godfrey, C.R.A. 1992. ICIA5504: a novel, broad spectrum, systemic bmethoxyacrylate fungicide. In: Proc. 1992 Brighton Crop Protection Conf. Pests Dis., 1: 435-442

Godwin, J.R., Young, J.E; Woodward, D.J. and Hart, C.A. 1997. Azoxystrobin: effect on the development of grapevine downy mildew (Plasmopara viticola). In: A.N.P.P. - Fifth Intern. Conf. on Plant Diseases, Tours (France), December, 3-5

Hagedorn, D. J. (1974). Recent pea anthracnose and downy mildew epiphytotic in Wisconsin. Plant Dis Rep. 58: 226-229.

Mence, M. J. and Pegg, G. F. 1971. The biology of Peronospora viciae on pea: factors affecting the susceptibility of plants to local infection and systemic colonization. Annals of Applied Biology, 67: 297-308.

\section{How to cite this article:}

Puja Pandey, K.P.S. Kushwaha and Vinod Upadhyay. 2017. Evaluation of Potential Fungicides and Bio Agents for the Management of Pea Downy Mildew and Yield under Field Condition. Int.J.Curr.Microbiol.App.Sci. 6(12): 1381-1388. doi: https://doi.org/10.20546/ijcmas.2017.612.154 